\title{
An Analytical Study of Growth of Indian Power Sector
}

\author{
Geetanjali Singh
}

\author{
Research Scholar, Department of Economics, Maharshi Dayanand University, Rohtak, Haryana, INDIA
}

\begin{abstract}
The power sector is one of the most critical growth drivers for any country. The power sector in India is highly regulated by the government and is dependent on the policies framed regarding bidding for power projects, regulations regarding transmission of power between states and pricing of power supply to consumer is also decided by the government. In India, the passage of the Electricity Act, 2003 brought about an impetus in the sector which paved way for new reforms in it. This paper firstly presents the overview of Indian power sector followed by analysis of growth of power sector in terms of installed generation capacity, electricity consumption, transmission and distribution losses ,number of villages electrified, length of T\&D lines and per capita consumption of electricity using compound annual growth rate .
\end{abstract}

KEYWORDS: Power Sector, Power Generation, Transmission and Distribution, Power Consumption, T\&D Loss, etc.

\section{INTRODUCTION}

India is a land of great diversity in terms of flora and fauna, climate and topography. Its unique identity among the nations of the world is due to its heritage of mountains, rivers and fertile land, etc. Its second position and the first position respectively in population and population density provide a different perspective to the global system altogether. All people use different types of resources for their well-beings, and energy resources are one of them. Energy is essential for nation's economic and social development. People use energy in the form of electricity, heat, oil, fuel gas and wood, etc. All the energy we use mainly comes from conventional sources. Due to the huge increase in population and changing lifestyle, the demand for energy is escalating consequently. All conventional energy resources are getting depleted at rapid rate. Currently, there is a lack of energy in India, which is borne out by power outages and increasing prices of other fuels. With regard to the future prospects of energy, the Indians may make sufficient use of unconventional energy sources such as wind, solar and geothermal Tidal power, etc. which is essential in times to come.

Reforms of power sector at the national level triggered the power sector Reforms in Haryana also. Orissa was the first state to introduce reforms in this sector by passing Orissa Act 1995. Under this Act, Orissa Generating Company, Grid Company and Orissa Electricity Regulatory Commission were established. Haryana government also followed suit and embarked upon the process of reforms in the power sector by breaking up the electricity board into different companies and Haryana Electricity Regulatory Commission was constituted.

State Electricity Regulatory commission Act was passed, leading to the establishment of central Electricity Regulatory Commission at the national level and State Electricity Regulatory Commission in the states. The purpose of this commission was to rationalize tariff and other matters related thereto. The enactment of ERC Act 1998 has induced more and more states to go ahead with the reform programmes. The governments of Uttar Pradesh, Rajasthan, Madhya Pradesh, Goa, Karnataka and Maharashtra are going to establish their independent regulatory mechanisms.

\section{LITERATURE REVIEW}

The researcher must be thoroughly familiar with both the previous theory and research, in order to occupy a place in the specific discipline. To assure this familiarity, a review of the research literature is done.

Anthonethe, et.al. (1999) viewed that "the Indian power sector was opened for private participation in 1991 to hasten the increase in generating capacity and to improve the system efficiency as well. Till early 1999 generation had commenced at private plants totally. In contrast some state had completed their projects even earlier than scheduled. The authors observed Independent Power Producers (IPP) have claimed that their progress has been hindered by problems: such as litigation problems, finance arrangements, and obtaining clearance and Fuel Supply Agreements. They also explained the process of inviting private participation in power sector, the problems experienced and suggested on the Restructuring of the Power Sector including the formation of Central and State Electricity Regulation Commission". Kumar (1999) has explained that "the process of power sector reform initiated in India in the early 1990's. Haryana was the second state after Orissa to undertake Power Sector Reforms under the overall supervision of the World Bank. The Haryana Electricity

DOI: 10.9790/0837-2206110613 www.iosrjournals.org 6 Page


Reforms Act, 1997 came into force with effect from 14 August, 1998. Consequently a number of structural changes were under taken. He examined the experience of electricity sector reform process in the context of Haryana State".

George (2000) points out that states are trying to meet the demand for electricity by generating power from non-hydro means such as coal, diesel etc. The data reveal the growing shift towards non-hydro options. However, the demand for non-hydro options does not pick up due to the following reasons. The coal abundant areas being fort away from the state, the generation of power from coal-based system becomes expensive and unviable. It becomes difficult to set up coal plants near the densely populated areas. Cost per unit of the power generated from non-hydro options being very high, its attraction lessens. But the Government of Kerala decided to produce power from non-hydro options. Since 2002, $50 \%$ of state electricity have been fulfilled from nonhydro sources.

Ranganathan (2004) stated that the 2003 Electricity Act opens the door to possibilities of competition and trade immensely but at the same time opens a new policy risk which it is supposed to mitigate. The law has a promotional framework to introduce competition in generating privatization in distribution but the homework in terms of dealing with the problem of transition was dropped.

Shahi (2005) analysed that "the energy sector presents a serious challenge for the development of infrastructure in India. A recent forecast of India's Planning Commission indicates that an investment of US \$ 300 billion is required for the development of the energy sector. In terms of per capita energy consumption, India is far below China, US, Russia, France, Germany, Japan and other countries around the world. The insufficient production of electricity and power has crippled industry, agriculture, commerce, trade and domestic consumers. Transmission and distribution losses of power have made it an expensive and restricted for India to enter into the global competition. Globalisation, macroeconomic and microeconomic reforms and outdated framework for the functioning of the energy sector in India initiated its privatization. This book also explained that the developed countries would stand to gain from the debate, by reflecting on the various models, they chose to the support developing countries in the development of their energy sector. At the micro front, the book has successfully highlighted the importance of power sector issues like debt -equity mix, commitment and risk management to the repatriation of dividends, technological up-gradation, reducing technical losses and theft".

Kumar (2014) analysed that in the last six and half decades, though India's energy use has increased 16 times and the installed energy capacity by 84 times, still India is facing the problem of acute power deficit. In order to meet the ever increasing power requirements, huge amount of power needs to be generated in the existing power sector. The National Electricity Policy envisaged "Power for all by 2012" whereas according to Ministry of Power statistics, the installed power generation capacity of India as on September 30, 2013 was 228721.73 (MW) and peak power shortage of around 9 per cent. However, the per capita energy consumption stood at 879 (KWH) as on March 2012. The demand of electricity has been increasing continually due to increasing population, urbanization and use of technology to access comfortable life. The present scenario indicates that India's future energy requirements are going to be extremely high. The losses due to transmission and distribution along with the problem of power theft in rural and urban areas are the areas of major concern of the present power system. Keeping in view the aforesaid, an intelligent and reliable power system is urgently required which can prevent the power theft problem and transmit the power at maximum effectively and efficiently.

World Bank (2014) reviewed Indian power sectors across key areas of access, utility performance and financial sustainability. It identified electricity distribution to the end consumer as the weak link in the sector. It recommended freeing utilities and regulators from external interference, increasing accountability and enhancing competition in the sector in order to move it to a higher level of service delivery.

\section{OBJECTIVES OF THE STUDY}

The main objective of this study is to analyse the growth of power sector in India in terms of:

- Installed Generation Capacity

- Electricity Consumption

- Transmission and Distribution Loss

- Number of Villages Electrified

- Length of T\& D Lines

- Per Capita Consumption

\section{RESEARCH METHODOLOGY}

The main source of data is Haryana Statistical Abstract (2015-16). This study considers the data from 1947-48 till 2014-15 using Compound Annual Growth Rate for analyzing data. Compound Annual Growth Rate is computed by using following formulae: 


$$
C A G R=\left[\frac{\text { Ending Value }}{\text { Beginning Value }}\right]^{\left[\frac{1}{\text { No. of years }}\right]}-1 \times 100
$$

\section{FINDINGS AND DISCUSSIONS}

The Electricity Act (EA), 2003.

All existing current laws such as the Indian Electricity Act, 1910, the Electricity Supply Act, 1948 and the Electricity Regulatory Commission Act 1998 etc. were abrogated, but several Reform Acts were not annulled.

The main purpose of the EA 2003 was to promote competition in every link of the power supply chain to enhance efficiency and reduce costs. For promoting competition a large number of sellers and buyers are required and this act seats to do it through its various provisions. It is EA 2003, which particularly focused on the timely restructuring of existing SEBS. Under this law, all SEBs have to be separated in generation, transmission and distribution. The model would be similar to that of the "World Bank" which was at first followed by Orissa and then copied by some other states.

This type of model is called the "single buyer" MODEL. This directive of EA 2003 was criticized and opined that restructuring should not be necessary as the vertical utilities are giving good results in some cases in India and abroad. Licensing has been completely abolished to improve generation. Only techno-economic clearance for hydro projects is needed. Open access in distribution will be introduced, enabling the majority of consumers to access power from another source, provided certain conditions are fulfilled. The pricing determination task has been delivered to regulatory commission. The constitution of State Regulatory commissions is compulsory. Electricity trade has been recognized as a distinct activity, but the regulatory commissions have the right to fix ceiling on trading margins if necessary. Consumer Redressed Forum Appellate Body and the Ombudsman have been established to safeguard the interests of consumers. 100 percent meeting is compulsory to minimize revenue losses.

\section{The Growth of the Power Sector in India}

The table 1 below highlights the pace of growth in the installed generation capacity since 1947-48 to 2014-15.This table also shows the growth in installed generation capacity in terms of CAGR. It is worth noting may be noted that total installed generation capacity increased from 1362 (MW) to 271722 in from 1947-48 to 2014-15. The Hydel generation capacity increased from 508(MW) to 41267 (MW) from 1947 to 2015. The total thermal generation capacity was 854 (MW) in 1947-48 and it has gone upto 188898(MW) till 2014-15. During the period under consideration, it was coal which has registered the maximum escalation in generation capacity from 756 (MW) in 1947-48 to 164636 (MW) in 2014-15. In the year 1947-48, renewable generation started only in the year 1991-92 with the capacity of 32 9MW) and has gone upto 35777 (MW) in 2014-15.

Table - 1 Growth Installed Generation Capacity in India: Mode Utilities wise

\begin{tabular}{|c|c|c|c|c|c|c|c|c|c|}
\hline \multirow[t]{2}{*}{ Sr. No. } & \multirow[t]{2}{*}{ Year } & \multirow[t]{2}{*}{ Hydro } & \multicolumn{4}{|c|}{ Thermal } & \multirow[t]{2}{*}{ Nuclear } & \multirow{2}{*}{$\begin{array}{c}\text { RES } \\
\#\end{array}$} & \multirow[t]{2}{*}{ Total } \\
\hline & & & Coal/ Lignite & Gas & Diesel & Total & & & \\
\hline 1 & $1947-48$ & 508 & 756 & 0 & 98 & 854 & 0 & 0 & 1362 \\
\hline 2 & $1949-50$ & 560 & 1004 & 0 & 149 & 1153 & 0 & 0 & 1713 \\
\hline 3 & $1955-56$ & 1361 & 1597 & 0 & 228 & 1825 & 0 & 0 & 2886 \\
\hline 4 & 1960-61 & 1917 & 2436 & 0 & 300 & 2736 & 0 & 0 & 4653 \\
\hline 5 & $1965-66$ & 4124 & 4417 & 134 & 352 & 4903 & 0 & 0 & 9027 \\
\hline 6 & 1968-69 & 5907 & 6640 & 134 & 276 & 7050 & 0 & 0 & 12957 \\
\hline 7 & 1973-74 & 6966 & 8652 & 165 & 241 & 9058 & 640 & 0 & 16664 \\
\hline 8 & $1978-79$ & 10833 & 14875 & 168 & 164 & 15207 & 640 & 0 & 26680 \\
\hline 9 & $1979-80$ & 11384 & 15991 & 268 & 165 & 16424 & 640 & 0 & 28448 \\
\hline 10 & 1984-85 & 14460 & 26311 & 542 & 177 & 27030 & 1095 & 0 & 42585 \\
\hline 11 & $1989-90$ & 18307 & 41236 & 2343 & 165 & 43764 & 1565 & 0 & 63636 \\
\hline 12 & $1991-92$ & 19194 & 44791 & 3095 & 168 & 48054 & 1785 & 32 & 69065 \\
\hline 13 & 1998-99 & 21658 & 54154 & 6562 & 294 & 61010 & 2225 & 902 & 85795 \\
\hline 14 & $2001-02$ & 26269 & 62131 & 11163 & 1135 & 74429 & 2720 & 1628 & 105046 \\
\hline 15 & 2006-07 & 34654 & 71121 & 13692 & 1202 & 86015 & 3900 & 7760 & 132329 \\
\hline 16 & 2012-13 & 39491 & 130221 & 20110 & 1200 & 151531 & 4780 & 27542 & 223344 \\
\hline 17 & 2013-14 & 40532 & 145273 & 21782 & 1200 & 168255 & 4780 & 31692 & 245259 \\
\hline 18 & 2014-15 & 41267 & 164636 & 23062 & 1200 & 1888898 & 5780 & 35771 & 271722 \\
\hline $1947-4$ & $\begin{array}{l}\text { GR } \\
\text { 2 2014-15 }\end{array}$ & 6.68 & 8.24 & 11.32 & 3.75 & 11.99 & 5.38 & 33.97 & 8.10 \\
\hline
\end{tabular}

Source: CEA Report (2015)

\{\#\} RES: Renewable Energy Sources includes Hydro capacity of 25.00 MW and below. 
In terms of CAGR, for the entire period under study, the total installed generation capacity increased at a rate of 8.10 per cent. The hydro generation capacity increased at a CAGR of 6.68 per cent. In case of nuclear generation capacity, it increased at a CAGR of 5.38 per cent.

Figure 1 Installed Generating Capacity (in 2014 -15)

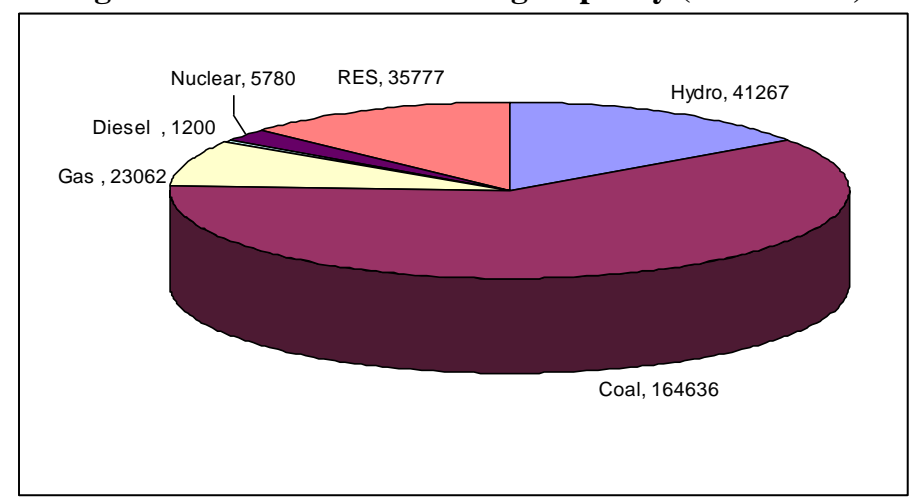

Source: CEA Report (2015)

The above pie chart shows the installed Generating capacity across all India as in 2014-15. The total installed generating capacity as on 31.3.2015 was 271722(MW). Coal generating capacity accounts for 58 per cent of the total installed generating capacity at $164636(\mathrm{MW})$, the highest of all categories of installed capacity. After coal, it was Hydro with capacity of 41267 (MW) and accounts for 18per cent of the total capacity. Renewable Energy, which has a rising trend to generate electricity has share of 35777 (MW) i.e. 12 per cent total installed generating capacity.

Table 3 given below showcases the Growth of electricity consumption in India in absolute and CAGR terms. India's per capita consumption has been growing over the years from 4181 (GWH) in 1947-48 to 938823 GWH in 2014-15. There has been a substantial change in the electricity consumption pattern across different consumer groups. The share of domestic sector has shot up from 423 (GWH) 1947-48 to 220894(GWH) in 2014-15. The share of commercial sector is lowest of all the sectors. Its share in the total electricity consumption was $178(\mathrm{GWH})$ in 1947-48 and has spiraled up to $82322(\mathrm{GWH})$ in 2014-15. The share of industrial sector in electricity consumption is highest of all the sectors at 395221(GWH) in 2014-15 from $2960(\mathrm{GWH})$ in 1947-48. The Per capita consumption of electricity in agriculture sector has been rising over the years. It has escalated up from $125(\mathrm{GWH})$ in $1947-48$ to $173200(\mathrm{GWH})$ in 2014-15.

Table 2 Growth of Electricity Consumption in India: Utilities and Non-Utilities

\begin{tabular}{|c|c|c|c|c|c|c|c|c|c|c|}
\hline Sr No. & Year & Domestic & \begin{tabular}{|c|} 
Percent to \\
Total
\end{tabular} & Commercial & $\begin{array}{c}\text { Percent to } \\
\text { Total }\end{array}$ & Industrial & $\begin{array}{c}\text { Percent to } \\
\text { Total }\end{array}$ & Agricultur & $\begin{array}{c}\text { Percent to } \\
\text { Total }\end{array}$ & Total \\
\hline 1 & $1947-48$ & 423 & 10.11 & 178 & 4.26 & 2960 & 70.78 & 125 & 2.99 & 4182 \\
\hline 2 & $1949-50$ & 525 & 9.36 & 309 & 5.31 & 4057 & 72.32 & 162 & 2.39 & 5610 \\
\hline 3 & $1955-56$ & 934 & 9.30 & 546 & 5.38 & 7514 & 74.63 & 316 & 3.11 & 10150 \\
\hline 4 & 1960-61 & 1492 & 8.88 & 848 & 5.05 & 12547 & 74.67 & 833 & 4.96 & 16804 \\
\hline 5 & $1965-66$ & 2355 & 7.73 & 1650 & 5.42 & 22596 & 74.13 & 1892 & 6.21 & 30455 \\
\hline 6 & $1968-69$ & 3184 & 7.65 & 2126 & 5.14 & 29931 & 72.31 & 3463 & 8.37 & 41392 \\
\hline 7 & 1973-74 & 4645 & 8.36 & 2988 & 5.36 & 37791 & 68.02 & 6310 & 11.36 & 55557 \\
\hline 8 & $1978-79$ & 7576 & 9.32 & 4330 & 5.15 & 54440 & 64.81 & 12628 & 14.32 & 84005 \\
\hline 9 & $1979-80$ & 8482 & 9.35 & 4657 & 5.46 & 33206 & 62.35 & 13452 & 15.76 & 85334 \\
\hline 10 & $1984-85$ & 15306 & 12.45 & 6537 & 5.37 & 73520 & 59.02 & 20961 & 16.83 & 124569 \\
\hline 11 & $1989-90$ & 25577 & 15.16 & 9540 & 4.89 & 100373 & 51.45 & 44056 & 22.58 & 195098 \\
\hline 12 & $1991-92$ & 35854 & 15.31 & 12633 & 5.20 & 110844 & 47.94 & 58557 & 25.33 & 231201 \\
\hline 13 & 1996-97 & 55267 & 17.53 & 17519 & 5.36 & 139253 & 44.17 & 84015 & 26.65 & 315294 \\
\hline 14 & 2001-02 & 75654 & 21.27 & 24139 & 6.44 & 159567 & 42.57 & 81673 & 21.80 & 374670 \\
\hline 15 & 2006-07 & 111002 & 21.12 & 40220 & 7.35 & 241216 & 45.39 & 99023 & 18.34 & 525673 \\
\hline 16 & 2012-13 & 183700 & 22.29 & 72794 & 8.83 & 365988 & 44.40 & 147462 & 17.89 & 824301 \\
\hline 17 & 2013-14 & 202297 & 22.95 & 77558 & 8.80 & 380605 & 43.17 & 160331 & 18.19 & 881562 \\
\hline 18 & $2014-15$ & 220894 & 23.53 & 82322 & 8.77 & 395221 & 42.10 & 173200 & 18.45 & 938823 \\
\hline $\mathrm{CA}$ & $\begin{array}{l}1947-48 \text { to } \\
14-15\end{array}$ & 9.64 & 1.25 & 9.44 & 1.07 & 7.46 & -0.76 & 11.22 & 2.71 & 8.29 \\
\hline
\end{tabular}

Source: CEA Report (2015)

For the entire period under study, the total electricity consumption of all sections increased at a CAGR of 8.29 per cent. For domestic consumer, the electricity consumption increased at a CAGR of 9.64 per cent. In case of commercial consumers the consumption increased at a CAGR of 9.44 per cent. The consumption of Industrial and Agriculture consumers increased at a CAGR of 7.46 and 11.22 per cent respectively. 
Table 3 Transmission and Distribution loss in India (Percent)

\begin{tabular}{|c|c|}
\hline Year & Transmission and Distribution Loss \\
\hline $1947-48$ & 14.88 \\
\hline $1948-50$ & 15.20 \\
\hline $1955-56$ & 13.80 \\
\hline $1960-61$ & 15.20 \\
\hline $1965-66$ & 14.60 \\
\hline $1968-69$ & 14.00 \\
\hline $1973-74$ & 20.50 \\
\hline $1978-79$ & 17.00 \\
\hline $1979-80$ & 20.40 \\
\hline $1984-85$ & 21.50 \\
\hline $1989-90$ & 23.30 \\
\hline $1991-92$ & 22.90 \\
\hline $1996-97$ & 22.80 \\
\hline $2001-02$ & 24.50 \\
\hline $2006-07$ & 28.55 \\
\hline $2012-13$ & 23.04 \\
\hline $2013-14$ & 21.46 \\
\hline $2014-15$ & 20.83 \\
\hline 15 & 0.50 \\
\hline CAGR 1947-48 to 2014- & \\
\hline & Source: CEA Report (2015) \\
\hline
\end{tabular}

Figure 2 Transmission and Distribution loss in India (1947-48 to 2014-15)

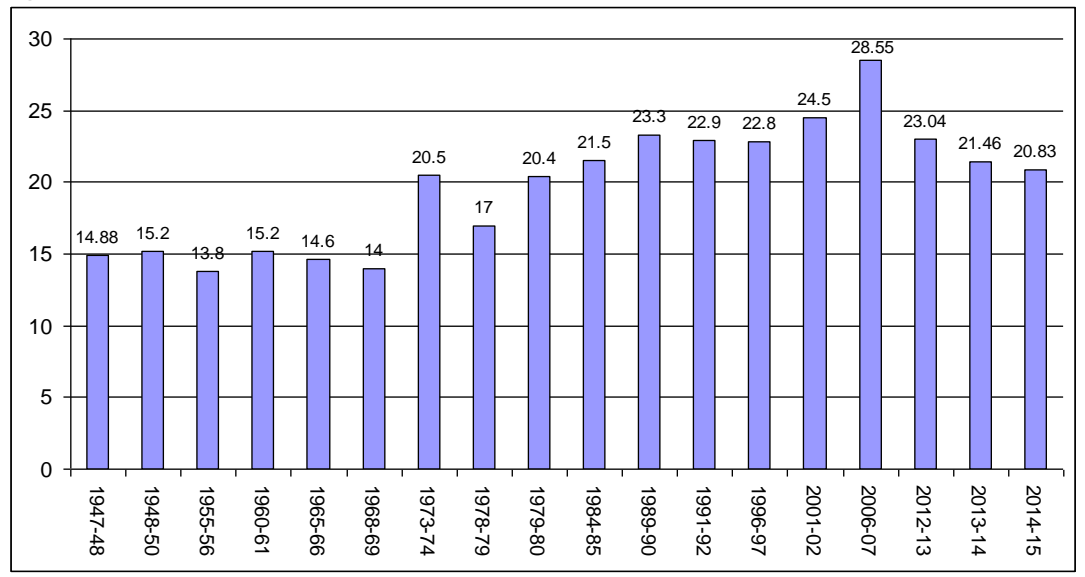

Source: CEA Report (2015)

Above given bar diagram depicts the transmission and distribution losses from the whole India in 194748 at the time of independence, it was only 14.88 per cent, which spurred to about 20.23 per cent in 1979-80. As far as figure is concerned, during 1980-2000 there was no major increase in T \& D loss. It was only in the year 2001-02, that T \& D loss went up to 33.98 per cent. But due to the positive impact of reforms on the power sector the T \& D loss started declining and plummeted to 23.83 per cent in 2014-15.

The table 4 shows the growth of electricity sector in India. To make the Growth of Electricity Sector in India explicit, we have analysed it in terms of CAGR. India is the world's 6th largest energy consumer and consumes 3.4 per cent of global energy .India's economic growth has led to rise in demand for energy at the average of 3.6 percent yearly over the last 30 years. The installed power generation capacity of India was 1362 MW in 1947-48 and has escalated to 271722 (MW) in 2014-15. Mission of power for all by 2012, enunciated by the government of India could materalise only if India has installed generation capacity of at least $20,0000 \mathrm{Mw}$ by 2013.That requirement was also fulfilled. For the entire period under study, the installed capacity increased at a CAGR of 8.10 per cent.

In absolute terms, the total fully electrified villages in $1949-1950$ were 3061 which rose to 577629 in 2014-15.Village electrification increased at a CAGR of 8.26 per cent. A village is presumed to be electrified if it has a basic infrastructure comprising of transformers and distribution lines; electricity is provided at public places and the number of houses electrified should be at least 10 per cent of the total number of households in the village. 
Table 4 Growth of Power Sector in India Utilities

\begin{tabular}{|c|c|c|c|c|c|}
\hline $\begin{array}{l}\text { Sr. } \\
\text { No. }\end{array}$ & Year & $\begin{array}{c}\text { Installed } \\
\text { Capacity (MW) }\end{array}$ & $\begin{array}{l}\text { Number of } \\
\text { Villages } \\
\text { Electrified }\end{array}$ & $\begin{array}{c}\text { Length of T \& D } \\
\text { Lines } \\
(\mathrm{kms} .) \#\end{array}$ & $\begin{array}{l}\text { Per Capita } \\
\text { Consumption } \\
(\$)(\mathbf{k W h})\end{array}$ \\
\hline 1 & $1947-48$ & 1362 & NA & 23238 & 16.30 \\
\hline 2 & $1949-50$ & 1713 & 3061 & 29271 & 18.20 \\
\hline 3 & $1955-56$ & 2886 & 7294 & 85427 & 30.90 \\
\hline 4 & 1960-61 & 4653 & 21754 & 157887 & 45.90 \\
\hline 5 & $1965-66$ & 9027 & 45148 & 541704 & 73.90 \\
\hline 6 & $1968-69$ & 12957 & 73739 & 886301 & 97.90 \\
\hline 7 & $1973-74$ & 16664 & 156729 & 1546097 & 126.20 \\
\hline 8 & $1978-79$ & 26680 & 232770 & 2145919 & 171.60 \\
\hline 9 & $1979-80$ & 28448 & 249799 & 2351609 & 172.40 \\
\hline 10 & 1984-85 & 42585 & 370332 & 3211956 & 228.70 \\
\hline 11 & $1989-90$ & 63636 & 470838 & 4407501 & 329.20 \\
\hline 12 & $1991-92$ & 69065 & 487170 & 4574200 & 347.50 \\
\hline 13 & $1998-99$ & 85795 & 498836 & 5141413 & 464.60 \\
\hline 14 & 2001-02 & 105046 & 512153 & 6030148 & 559.20 \\
\hline 15 & $2006-07$ & 132329 & 482864 & 6939894 & 671.90 \\
\hline 16 & $2012-13$ & 223343 & 560552 & 9080556 & 914.40 \\
\hline 17 & 2013-14 & 245259 & 572414 & 9534584 & 957.00 \\
\hline 18 & 2014-15 & 271722 & 577629 & 10558177 & 1010 \\
\hline 1947 & $\begin{array}{l}\text { CAGR } \\
-48 \text { to } 2014- \\
15\end{array}$ & 8.10 & 8.26 & 9.42 & 6.26 \\
\hline
\end{tabular}

Source: CEA Report (2015)

N A: Not Available.

\$ Per Capita Consumption: Gross Electrical Energy Availability/Mid year Population

(\#): Includes 440 Volts Distribution Lines.

The Government of India has undertaken a number of policies and programs for being qualified as a electrified village. National Electricity Policy, 2005 and the National Policy for Rural Electrification, 2006, Rural electrification programs, Deen Dayal Upadhyaya Jyoti Gram Yojana, Rajeev Gandhi Grameen Vidyutikaran Yojana, remote village electrification program, village energy security programs, etc. are the government policies for rural electrification.

Transmission of electricity is defined as bulk transfer of power over a long distance at high voltage, generally of $132(\mathrm{KV})$ and above. In absolute term, the length of transmission and distribution lines were 23238 $(\mathrm{Km})$ in 1947-48 and are now $10558177(\mathrm{Km})$ in 2014-15.For the period under study, it has increased at a CAGR of 9.42 per cent.

The fast growth of Indian Economy has triggered escalating demand for energy at an average of 3.6 per cent yearly over the last 30 years. The per capita consumption of electricity has gone up from $16.3(\mathrm{KWH})$ in 1947-48 to 1010 (KWH) in 2014-15. From the above given table, it can be deduced that the per capita consumption of electricity has increased at a CAGR of 6.26 per cent.

\section{Rural Electrification in India}

Rural electrification aims to supply energy for two types of programmes: (a) production-oriented activities like minor irrigation, rural industries etc. and (b) electrification of villages. Rural Electrification Corporation (REC) was constituted in July 1969 to finance different projects of rural electrification. REC is a Public Financial Institution under section 4A of the Companies Act, 1956. REC is also registered as a NonBanking Financial Company (NBFC) under section 451A of RBI Act, 1934. At present REC is a 'Navratna' Company. The current mission of REC is to facilitate the availability of electricity to increase the pace of growth and for improvement of quality of life of rural and semi-urban population and also to act as a competitive, client-friendly and development oriented organisation to finance and promote projects covering power generation, power conservation, power transmission and power distribution network in the country. To give impetus to rural electrification, the Government has given special attention to creation and augmentation of Rural Electricity Distribution Backbone and Village Electricity Infrastructure so as to provide electricity to all villages and rural households in a period of five years. Rural Electricity Supply Technological Mission (REST) has been established to monitor the implementation of schemes under Accelerated Rural Electrification Programme.

\section{Rural Electrification Policy}

On August 23, 2006, Government notified Rural Electrification Policy under section 4 and 5 of the Electricity Act, 2003. The policy aims to provide access to electricity to all households by year 2009. It will also ensure that quality and reliable power supply is made available at reasonable rates with minimum lifeline 
consumption of 1 unit per household per day as a merit good by year 2012.

\section{Rajeev Gandhi Gramin Vidyutikaran Yojana (RGGVY)}

To ensure the electrification of all villages and habitations, and to provide electricity to all rural houses and providing free electricity connection to families below the poverty line, Prime Minister Dr. Manmohan Singh launched a new Scheme RGGVY on April 4, 2005. To achieve the targets, minimum one $33 / 11$ K.V. or $66 / 11$ K.V sub-station will be established in each block as a Rural Electricity Distribution Backbone (REDB) and also minimum one distribution transformer will be established in each village as Village Electrification Infrastructure (VEI). The places where electric supply is not possible/cost effective through grid, Decentralised Distribution Generation (DDG) Systems will be under under the new scheme 90per cent of capital cost will be provided by the centre as subsidy.

The scheme aims at completing electrification of all un-electrified villages and un-electrified hamlets in the next five years. The scheme provides for financing of electrification of all unelectrified Below Poverty Line (BPL) households in the country with 100 per cent capital subsidy as per norms of Kutir Jyoti Programme in all rural habitations.For projects to be eligible for capital subsidy under this scheme before sanctioning the projects ,prior commitment of the state would be taken for : (i) deployment of franchisees for the management of rural distribution in projects financed under this scheme (ii) provision of requisite revenue subsidy to the State utilities as required under the Electricity Act, 2003.

\section{Remote Village Electrification Programme}

To provide basic lighting electricity facilities through renewable energy sources under Remote Village Electrification (RVE) Programme, special priority has been accorded to villages affected by internal disturbances. During 2010-11, 1537 remote villages and hamlets were provided solar home-lighting systems under the programme, taking the cumulative achievement to 8,104 remote villages and remote hamlets.

\section{CONCLUSION}

Power is one of the most critical components of infrastructure crucial for the economic growth and welfare of nations. The existence and development of adequate infrastructure is essential for sustained growth of the Indian economy. India's power sector is one of the most diversified in the world. Sources of power generation range from conventional sources such as coal, lignite, natural gas, oil, hydro and nuclear power to viable non-conventional sources such as wind, solar, and agricultural and domestic waste. Electricity demand in the country has increased rapidly and is expected to rise further in the years to come. India's economic growth has led to rise in demand for energy at the average of 3.6 percent yearly over the last 30 years. In order to meet the increasing demand for electricity in the country, massive addition to the installed generating capacity is required. The installed power generation capacity of India was $1362 \mathrm{MW}$ in 1947-48 and has escalated to 271722 (MW) in 2014-15 The per capita consumption of electricity has gone up from 16.3 (KWH) in 1947-48 to $1010(\mathrm{KWH})$ in 2014-15. In absolute terms, the length of transmission and distribution lines were 23238 $(\mathrm{Km})$ in 1947-48 and are now $10558177(\mathrm{Km})$ in 2014-15. The total fully electrified villages in 1949-1950 were 3061 which grew upto 577629 in 2014-15.Village electrification increased at a CAGR of 8.26 per cent.

Furthermore, the world is now looking to green energy technologies for the future. Renewable energy is an excellent solution for this. The time for transition to an energy future that has a significant component of renewable energy has come with emphasis on solar energy, wind energy, small hydro power, biofuels, biomass energy, biogas. Clean energy is fundamental for socio-economic development and poverty reduction. Ending poverty requires confronting climate change, which affects every nation and every person.

\section{BIBLIOGRAPHY}

[1] Antoinette D., K.V. Narasimha Murthy, and Amulya K. N. Reddy. 1999. "India's Power Sector Liberalization : An Overview". Economic and Political Weekly, Vol. 34(23), pp. 11

[2] Baijal, Pradip. 1996. "Restricting Power Sector in India: A Base Paper". Economic and Political Weekly, Vol.34 (39), pp. 2795.

[3] Bajaj, J.L. 2004. "Power Sector Reforms in India: Regulatory Issues". IIMB Management Review. Vol. 34(81), pp 37-60.

[4] Bhattacharyya, C.S. 1999. "An Overview of Problems and Prospects for the Indian Power Sector". Energy Review, Vol. 19(12), pp.795-80.

[5] Central Electricity Authority. 2012. Monthly Electricity Generation Report. New Delhi.

[6] Dubash, N.K., and S.C. Ranjan. 2001. "Power Politics, Process of Power Sector Reforms in India". Economic and Political Weekly, Vol. 36(35), pp. 3357-3390.

[7] George, A. 2000. "An Overview of Electricity Sector in Kerala". Prayas and Focus on the Global South, Mumbai.

[8] Government of Haryana. 2015. Statistical Abstract of Haryana, Planning Department, Govt. of Haryana, Chandigarh.

[9] Kumar, Surinder. 1999. "The State Subsidisation and Pricing Policy in Electricity Supply: A Case Study of Haryana State". Indian Journal of Power and River Valley Development, Calcutta, pp.29-39.

[10] Kumar, Ashish, Denish Chaudhary and Shubham Tyagi, 2014. "Indian Power Sector at A Glance: A Review". International 
Journal of Forging Technology and Advanced Engineering, Vol 4 (1), pp. 98-100.

[11] Mathur, Neerja. 2010. "Overview of Indian Power Sector". Presentation at Joint IEA-India Workshop on Industrial Energy Efficiency, New Delhi.

[12] Mitra, Partha Pratim. 1996. "Power Sector in India Issues and Challenges". Yojana, November.

[13] Parikh, Joyti K., and Kirit S. Parikh. 2002. "Reforms in the Power Sector". In India Development Report 2002 (ed.) by National Council for Applied Economic Research, New Delhi.

[14] Ranganathan, V. 2004. "Electricity Act 2003,Moving to a Competitive Environment". Economic and Political Weekly, Vol. 39(20),pp. 2001-05.

[15] Shahi, R.V. 2005. "Indian Power Sector: Challenge and Response". Compilation of Papers Presented during 1991-2001. New Delhi: Excel Books

[16] Singh, Anoop. 2006. "Power Sector Reform in India: Current Issues and Prospects". Energy Policy, Vol. 34(16), pp. 2480-2490.

[17] The Energy and Resources Institute. 2015. TERI Energy Data, Directory and Yearbook 2014. TERI, New Delhi.

[18] Wood, G.D. and D. Kodwani. 1997. "Privatisation Policy and Power Sector Reforms: Lessons from British Experience for India". Economic and Political Weekly, Vol. 32(37), pp. 2350-2358.

[19] World Bank. 2014. "More Power to India: The Challenge of Electricity Distribution”. Washington, D.C. 